J. Amer. Soc. Hort. ScI. 115(4):674-677. 1990.

\title{
Inheritance of Prostrate Growth Habit in Tomato
}

\author{
Richard H. Ozminkowski, Jr. ${ }^{1}$, Randolph G. Gardner ${ }^{2}$, Robert H. Moll ${ }^{3}$, and \\ Warren R. Henderson ${ }^{4}$ \\ Department of Horticultural Science, Box 7609, North Carolina State University, Raleigh, \\ NC 27695-7609 \\ Additional index words. breeding, Lycopersicon esculentum, heritability, quantitative inheritance, plant habit
}

\begin{abstract}
Prostrate growth habit (PGH) in tomato (Lycopersicon esculentum Mill.) lines derived from breeding material developed at the Agriculture Canada Research Station, Beaverlodge, Alberta, was the subject of a quantitative inheritance study. Plants with PGH have an increased lateral branch angle, relative to upright plants, and crown-set fruit supported above the soil surface making hand harvest easier. Genetic parameters were estimated in two families (20G and 53G), each containing PGH and upright-habit parental lines, $F_{1}, F_{2}$, and backcrosses to each parent. Field-grown plants were subjectively rated twice during the growing season. Broad-sense heritability of PGH in family $20 \mathrm{G}$ was estimated to be 0.65 and 0.71 for ratings of plant growth habit 6 and 9 weeks after transplanting, respectively, and 0.71 and 0.68 for those of family 53G. Narrow-sense heritability was estimated to be 0.83 and 1.05 for the two ratings in the $20 \mathrm{G}$ family and 0.77 and 0.78 in the $53 \mathrm{G}$ family. $F_{1}$ and $F_{2}$ means were not different from mid-parent values. The genetic variance was entirely additive and expression was influenced by the environment. The data did not support the hypothesis that PGH was controlled by a single gene.
\end{abstract}

Many genes have been described that affect plant habit and/ or branching in tomato. Among these are decumbens (dec) (Stubbe, 1959), procumbens-2 (prc-2) (Stubbe, 1960), and brachytic (br) (Barton et al., 1955). Genes causing an increase in lateral branching include erecta-2 (er-2) (Clayburg et al., 1979), globiformis ( $\mathrm{glf}$ ), and globosa-2 (glo-2) (Clayburg et al., 1966). Increased branching may be due to reduced apical dominance (Campbell and Nonnecke, 1974).

Lateral promoter $(L p)$ has been described in lines derived from breeding material developed at the Agriculture Canada Research Station, Beaverlodge, Alberta (Campbell and Nonnecke, 1974). The gene $L p$ is partially dominant and causes the formation of lateral branches at the cotyledonary node upon an early termination of the main axis. Other laterals follow in sequence proximally, and defoliation is early (I.L. Nonnecke, personal communication).

The objective of this study was to estimate the inheritance of prostrate growth habit (PGH) in fresh-market tomato breeding lines derived from Beaverlodge material. This trait has been studied and found to increase the percentage of marketable fruit

Received for publication 7 Aug. 1989. Paper no. 12273 of the Journal Series of the North Carolina Agricultural Research Service, Raleigh, NC 27695. We acknowledge the technical assistance of Tom Eaker and Rebecca Wells. The cost of publishing this paper was defrayed in part by the payment of page charges. Under postal regulations, this paper therefore must be hereby marked advertisement solely to indicate this fact.

'Former Graduate Research Assistant. Present address: Dept. of Horticulture, The Ohio State Univ., Columbus, OH 43210.

${ }^{2}$ Associate Professor.

${ }^{3}$ Professor of Genetics.

${ }^{4}$ Associate Professor. produced in ground culture by decreasing the percentage of decayed fruit (Ozminkowski et al., 1990).

\section{Materials and Methods}

Two fresh-market breeding lines, NC 20G (an $\mathrm{F}_{5}$ ) and NC $53 \mathrm{G}$ (an $\mathrm{F}_{4}$ ), were the source of PGH in this study. These lines were developed by R.G. Gardner at the Mountain Horticultural Crops Research and Extension Center, Fletcher, N.C. Both lines inherited PGH from a common breeding line, BHN 823125-1, obtained from J.J. Augustine in 1983. NC 20G is determinate ( $s p$ gene), with early maturity and a small plant habit, whereas $\mathrm{NC} 53 \mathrm{G}$ is a large, determinate plant with late maturity.

Fruit were harvested in the field from a single plant of each line, resulting in lines NC 20G-1 and NC 53G-1. Seeds of both PGH lines and 'Piedmont' (Gardner, 1985), having an upright plant habit, were planted in the greenhouse and grown to maturity in individual n-liter nursery pots. Plants were staked for ease of handling.

Both PGH lines contained the jointless fruit pedicel allele (j2). Two $F_{1}$ hybrids were produced using 'Piedmont' (having the dominant allele-jointed fruit pedicel) as the pollen parent. Accidental self-pollination of the female parents would be seen in presumptive $\mathrm{F}_{1} \mathrm{~S}$ and as improper segregation ratios of the $j 2$ allele in segregating generations. These pollinations gave rise to two families, 20G and 53G.

Parental and $F_{1}$ seeds were collected and planted in the greenhouse as described above. The pots were arranged in a randomized complete-block design with six replications. A replication consisted of one plant each of the three parents and the two $\mathrm{F}_{1} \mathrm{~s}$. Eleven weeks after seeding, lateral branch angles were measured on each plant by use of a hand protractor. The angle was 
measured at a point $\approx 5 \mathrm{~cm}$ from the intersection of the branch and main stem. Backcrosses were made of the $F_{1} s$ to both of their respective parents (within each family). Self-pollination of the $\mathrm{F}_{1}$ produced $\mathrm{F}_{2}$ seed for each family.

Seed was planted and grown for 4 weeks in a greenhouse in $125-\mathrm{cm}^{3}$ individual cells containing a peat-lite medium. The field was tilled, with fertilizer added at (in $\mathrm{kg} \cdot \mathrm{ha}^{-1}$ ) $33.5 \mathrm{~N}-$ $132 \mathrm{P}-252 \mathrm{~K}$. Plants were set by hand into 0.9-m-wide raised beds covered with black plastic mulch. Plant spacing was 1.5 $\mathrm{m}$ between and $0.6 \mathrm{~m}$ within rows. Dead plants were replaced during the first 14 days.

The experimental design was a split-plot with four replications. Families were main plots and generations were subplots with six plants each. Each replication of a family consisted of one plot each of the parental lines and $F_{1}$, five plots each of the two backcrosses, and 10 plots of the $\mathrm{F}_{2}$ populations. Each plant was considered an experimental unit.

Three weeks after transplanting, two lateral branch angles were measured on each plant as described above. The first of two subjective ratings of plant habit was done 6 weeks after transplanting. A rating scale of 1 (upright growth habit similar to 'Piedmont') to 5 (extreme PGH) was used. A second rating was done 3 weeks later.

Mean branch angles and plant habit ratings of generations were compared using Student's $t$ test for unequal variances (Steele and Torrie, 1980). The calculations were done on a per plant basis, analyzing each family and each rating date separately. The genetic parameters estimated were the genotypic, environmental, additive, and nonadditive variances, and broad-sense and narrow-sense heritabilities (Ozminkowski, 1988; Warner, 1952). Standard errors were calculated for the four variances.

To test the hypothesis that the trait was governed by a single locus, observed means $(\mathrm{M})$ and variances $(\mathrm{V})$ of each $\mathrm{F}_{2}$ population were compared with those predicted by a single-gene model, $\mathrm{P}\left(\mathrm{M}_{\mathrm{F} 2}\right)$ and $\mathrm{P}\left(\mathrm{V}_{\mathrm{F} 2}\right)$, respectively. These predicted values were computed as follows: $\mathrm{P}\left(\mathrm{M}_{\mathrm{F} 2}\right)=0.25\left(\mathrm{M}_{\mathrm{P} 1}\right)+0.50\left(\mathrm{M}_{\mathrm{F1}}\right)$ $+0.25\left(\mathrm{M}_{\mathrm{P} 2}\right)$ and $\mathrm{P}\left(\mathrm{V}_{\mathrm{F} 2}\right)=0.25\left(\mathrm{M}_{\mathrm{P} 1}{ }^{2}\right)+0.50\left(\mathrm{M}_{\mathrm{F} 1}{ }^{2}\right)+$ $0.25\left(\mathrm{M}_{\mathrm{P} 2}{ }^{2}\right)-\mathrm{P}\left(\mathrm{M}_{\mathrm{F} 2}\right)^{2}$. The means were compared using Student's $t$ test, while a $x^{2}$ with the normal probability function (Fisher and Yates, 1963) served to compare the observed and expected variances.

\section{Results and Discussion}

Branch angle measurements taken in the greenhouse showed that the second, third, and fourth branch angles above the soil and the main branch angle (immediately below the first inflorescence) were greater in the PGH parents than in 'Piedmont' (Table 1). There was no significant difference between the two PGH parents; the branch angles of both hybrids were intermediate to their parents.

Mean angle measurements of the first and second lateral branch angle above the cotyledons on field-grown plants exhibited similar relationships to those obtained in the greenhouse (Tables 1 and 2). Both lateral branch angles were higher in the PGH parents than in 'Piedmont'. The first angle of the $F_{1}$ generation was intermediate to the parents in both the $20 \mathrm{G}$ and $53 \mathrm{G}$ families. This was not the case of the second angle, which was not significantly different from the PGH parent in either family. Backcrosses generally ranged between the $F_{1}$ and their respective parent, with the exception of the second angle of the $\mathrm{BC}_{2}$ in the $53 \mathrm{G}$ family, where the mean of the $\mathrm{BC}_{2}$ was less than that of the $\mathrm{P}_{2}$, yet this was not significant. Based on greenhouse
Table 1. Mean lateral branch angle (in degrees) of greenhouse-grown tomato plants.

\begin{tabular}{lcccc}
\hline \hline & \multicolumn{4}{c}{ Branch $^{\mathrm{z}}$} \\
\cline { 2 - 5 } Parent or hybrid & Second & Third & Fourth & Main \\
\hline NC 20G-1 & $63 \mathrm{a}^{\mathrm{y}}$ & $58 \mathrm{a}$ & $71 \mathrm{a}$ & $77 \mathrm{a}$ \\
NC 53G-1 & $60 \mathrm{a}$ & $63 \mathrm{a}$ & $60 \mathrm{a}$ & $74 \mathrm{a}$ \\
NC 20G-1 $\times$ Piedmont & $42 \mathrm{~b}$ & $41 \mathrm{~b}$ & $44 \mathrm{~b}$ & $63 \mathrm{~b}$ \\
NC 53G-1 $\times$ Piedmont & $47 \mathrm{~b}$ & $41 \mathrm{~b}$ & $55 \mathrm{c}$ & $58 \mathrm{~b}$ \\
Piedmont & $32 \mathrm{c}$ & $36 \mathrm{~b}$ & $32 \mathrm{~d}$ & $50 \mathrm{c}$ \\
\hline
\end{tabular}

${ }^{2}$ Second, third, and fourth branch angles are at nodes from base of plant upward; main branch angle is angle formed by the main stem and lateral shoot immediately below first inflorescence.

'Means within the same column followed by the same letter are not significantly different in a one-tailed Student's $t$ test at $P=0.05,10$ df.

Table 2. Means of the first and second lateral branch angles ${ }^{2}$ (in degrees) for the generations of $\mathrm{P}_{1}, \mathrm{BC}_{1}, \mathrm{~F}_{1}, \mathrm{~F}_{2}, \mathrm{BC}_{2}$, and $\mathrm{P}_{2}$ in fieldgrown tomato plants.

\begin{tabular}{llllll}
\hline \hline & \multicolumn{2}{c}{ 20G Family } & & \multicolumn{2}{c}{$53 \mathrm{G}$ Family } \\
\cline { 2 - 3 } \cline { 5 - 6 } Generation & First & Second & First & Second \\
\hline & $52 \mathrm{a}$ & $43 \mathrm{ab}$ & $51 \mathrm{a}$ & $51 \mathrm{a}$ \\
$\mathrm{P}_{1}(\mathrm{PGH})$ & $47 \mathrm{~b}$ & $43 \mathrm{a}$ & & $48 \mathrm{a}$ & $44 \mathrm{~b}$ \\
$\mathrm{BC}_{1}$ & $45 \mathrm{bc}$ & $44 \mathrm{a}$ & & $43 \mathrm{~b}$ & $40 \mathrm{bc}$ \\
$\mathrm{F}_{1}(\mathrm{PGH} \times$ Piedmont) & $43 \mathrm{c}$ & $39 \mathrm{~b}$ & & $43 \mathrm{~b}$ & $40 \mathrm{c}$ \\
$\mathrm{F}_{2}$ & $36 \mathrm{~d}$ & $36 \mathrm{c}$ & & $42 \mathrm{~b}$ & $35 \mathrm{~d}$ \\
$\mathrm{BC}_{2}$ & $33 \mathrm{~d}$ & $33 \mathrm{c}$ & & $32 \mathrm{c}$ & $40 \mathrm{bcd}$ \\
$\mathrm{P}_{2}$ (Piedmont) & &
\end{tabular}

${ }^{2}$ Branch angle 1 and 2 are the angles formed by the main stem and the first and second lateral branch from the soil surface, respectively.

'Means within the same column followed by the same letter are not significantly different in a one-tailed Student's $t$ test at $P=0.05$.

Table 3. Growth habit ratings at 6 and 9 weeks after transplanting for five generations of two families of field-grown tomatoes.

\begin{tabular}{|c|c|c|c|}
\hline \multirow[b]{2}{*}{ Generation } & \multirow{2}{*}{$\begin{array}{l}\text { No. } \\
\text { plants }\end{array}$} & \multicolumn{2}{|c|}{ Rating $2, y$} \\
\hline & & 6 Weeks & 9 Weeks \\
\hline & & \multicolumn{2}{|c|}{$20 G$ Family } \\
\hline $\mathrm{P}_{1}(\mathrm{NC} 20 \mathrm{G}-1)$ & 24 & $4.2 \mathrm{a}$ & $4.4 \mathrm{a}$ \\
\hline $\mathrm{BC}_{1}$ & 116 & $4.1 \mathrm{a}$ & $4.1 \mathrm{a}$ \\
\hline $\mathrm{F}_{1}(\mathrm{NC} 20 \mathrm{G}-1 \times$ Piedmont $)$ & 23 & $3.1 \mathrm{~b}$ & $3.1 \mathrm{~b}$ \\
\hline $\mathrm{F}_{2}$ & 238 & $3.0 \mathrm{~b}$ & $2.8 \mathrm{~b}$ \\
\hline $\mathrm{BC}_{2}$ & 120 & $2.0 \mathrm{c}$ & $1.9 \mathrm{c}$ \\
\hline \multirow[t]{2}{*}{$\mathrm{P}_{2}$ (Piedmont) } & 24 & $1.3 \mathrm{~d}$ & $1.4 \mathrm{~d}$ \\
\hline & & \multicolumn{2}{|c|}{$53 G$ Family } \\
\hline $\mathrm{P}_{1}(\mathrm{NC} 53 \mathrm{G}-1)$ & 24 & $4.5 \mathrm{a}$ & $4.5 \mathrm{a}$ \\
\hline $\mathrm{BC}_{1}$ & 118 & $3.6 \mathrm{~b}$ & $3.8 \mathrm{~b}$ \\
\hline $\mathrm{F}_{1}(\mathrm{NC} 53 \mathrm{G}-1 \times$ Piedmont $)$ & 23 & $3.2 \mathrm{c}$ & $3.2 \mathrm{c}$ \\
\hline $\mathrm{F}_{2}$ & 239 & $2.6 \mathrm{~d}$ & $2.9 \mathrm{c}$ \\
\hline $\mathrm{BC}_{2}$ & 119 & $2.0 \mathrm{e}$ & $1.8 \mathrm{~d}$ \\
\hline $\mathrm{P}_{2}$ (Piedmont) & 24 & $1.4 \mathrm{f}$ & $1.5 \mathrm{~d}$ \\
\hline
\end{tabular}

${ }^{2}$ Subjective ratings from 1 to $5 ; 1=$ upright, $5=$ prostrate growth habit.

"Values within a column and family followed by the same letter are not significantly different at $P=0.05$ according to a Student's $t$ test with unequal variances.

and field data, PGH was genetically controlled and resulted in an increased lateral branch angle.

Mean ratings of plant growth habit of the PGH lines (NC 20G-1 and NC 53G-1) were much greater than those of 'Piedmont' for each rating date in both families (Table 3). The mean 
values of the $F_{1}$ and the $F_{2}$ were intermediate to those of their parents. Except for the 6-week rating in the $53 \mathrm{G}$ family, means of the $F_{1}$ and $F_{2}$ were not significantly different.

In the $20 \mathrm{G}$ family, there was no significant difference in means between the $\mathrm{P}_{1}$ and the $\mathrm{BC}_{1}$. In the $53 \mathrm{G}$ family, the $\mathrm{BC}_{1}$ ratings were closer to $\mathrm{P}_{1}$ than $\mathrm{P}_{2}$ and differed from both parents. Differences occurred between the $\mathrm{P}_{2}$ and $\mathrm{BC}_{2}$ generations, except on the 9 -week rating date in the $53 \mathrm{G}$ family. In all cases, the two backcrosses, $\mathrm{BC}_{1}$ and $\mathrm{BC}_{2}$, were different.

A trait is completely additive when the means of the $\mathrm{F}_{1}$ and $\mathrm{F}_{2}$ are equal to that of the mid-parent and when the variance of the $\mathrm{F}_{2}$ is equal to the sum of the variances of the two backcrosses, assuming no linkage (Wright, 1968). The means of the $F_{1}$ and $F_{2}$ were not significantly different from that of the midparent, with the exception of the 6-week rating in the $53 \mathrm{G}$ family, where the $\mathrm{F}_{2}$ was significantly lower than the mid-parent and $F_{1}$ means (data not shown). The sum of the backcross variances and that of the $\mathrm{F}_{2}$ did not differ at the 0.05 level in any case. Thus, PGH was inherited in a completely additive manner.

Estimates of genotypic variances ranged between 0.89 and 1.73 (Table 4). The environmental variances were lower than the genotypic variances, ranging from 0.37 to 0.69 . Estimates of heritabilities were found to be high, with a range for the broad-sense $(\mathrm{H})$ between 0.65 and 0.71 , and 0.77 to 1.05 for the narrow-sense $\left(h^{2}\right)$. The genotypic variance was completely accounted for by additive variance. Estimates of non additive variances were uniformly negative, with standard errors making them likely to be either zero or a very small positive value (Lindsey et al., 1962). The negative estimates of nonadditive variances explain the higher estimates of narrow-sense heritability than broad-sense.

Predicted means based on a single-locus model, as compared to observed $\mathrm{F}_{2}$ means (Table 5), were different for family $53 \mathrm{G}$, but not for family 20G. Variance estimates differed from predicted with one exception-the 6-week rating for 53G family.

Table 4. Estimates of variances, standard errors, and heritabilities of $\mathrm{PGH}$ in two tomato breeding-lines based on growth habit ratings at 6 and 9 weeks after transplanting.

\begin{tabular}{|c|c|c|c|c|}
\hline \multirow[b]{2}{*}{ Parameter } & \multicolumn{2}{|c|}{6 Weeks } & \multicolumn{2}{|c|}{9 Weeks } \\
\hline & Value & $\mathrm{SE}^{\mathrm{Z}}$ & Value & $\mathrm{SE}^{\mathrm{z}}$ \\
\hline & \multicolumn{4}{|c|}{$20 G$ Family } \\
\hline \multicolumn{5}{|l|}{ Variance } \\
\hline Genotypic & 0.91 & 0.15 & 1.73 & 0.25 \\
\hline Environmental & 0.49 & 0.08 & 0.69 & 0.12 \\
\hline Additive & 1.17 & 0.30 & 2.53 & 0.49 \\
\hline Nonadditive & -0.26 & 0.33 & -0.80 & 0.55 \\
\hline \multicolumn{5}{|l|}{ Heritability } \\
\hline Broad-sense & 0.65 & & 0.71 & \\
\hline \multirow[t]{2}{*}{ Narrow-sense } & 0.83 & & 1.05 & \\
\hline & \multicolumn{4}{|c|}{$53 G$ Family } \\
\hline \multicolumn{5}{|l|}{ Variance } \\
\hline Genotypic & 0.89 & 0.13 & 1.44 & 0.22 \\
\hline Environmental & 0.37 & 0.06 & 0.67 & 0.11 \\
\hline Additive & 0.97 & 0.27 & 1.64 & 0.45 \\
\hline Nonadditive & -0.07 & 0.30 & -0.20 & 0.50 \\
\hline \multicolumn{5}{|l|}{ Heritability } \\
\hline Broad-sense & 0.71 & & 0.68 & \\
\hline Narrow-sense & 0.77 & & 0.78 & \\
\hline
\end{tabular}

${ }^{\mathrm{z}}$ Standard error (SE) of the variances calculated using the formula $\mathrm{SE}\left(\mathrm{V}_{\mathrm{x}}\right)=\left\{2 \Sigma\left[\mathrm{C}^{2}(\mathrm{~V})^{2} /(\mathrm{df}+2)\right]\right\}^{1 / 2}$, summed over all contributing variances $(V)$, with degrees of freedom (df). C $=$ coefficient of variance component.
Table 5. Observed means and variances in plant growth habit ratings at 6 and 9 weeks after transplanting of tomato $F_{2}$ populations segregating for $\mathrm{PGH}$ and those predicted by a single-gene model.

\begin{tabular}{|c|c|c|c|c|}
\hline \multirow[b]{2}{*}{ Parameter } & \multicolumn{2}{|c|}{ NC 20G-1 $\times$ Piedmont } & \multicolumn{2}{|c|}{ NC 53G-1 $\times$ Piedmont } \\
\hline & 6 Weeks & 9 Weeks & 6 Weeks & 9 Weeks \\
\hline \multicolumn{5}{|l|}{ Mean rating $z, y$} \\
\hline Observed & 3.0 & 2.8 & $2.6 \mathrm{a}$ & 2.9 \\
\hline Predicted ${ }^{\mathbf{x}}$ & 2.9 & $3.0 \mathrm{a}$ & $3.1 \mathrm{~b}$ & 3.1 \\
\hline \multicolumn{5}{|l|}{ Variance $^{\mathrm{w}}$} \\
\hline Observed & $1.40 \mathrm{a}$ & $2.42 \mathrm{a}$ & $1.26 \mathrm{a}$ & $2.10 \mathrm{a}$ \\
\hline Predicted $^{v}$ & $1.07 \mathrm{~b}$ & $1.10 \mathrm{~b}$ & $1.26 \mathrm{a}$ & $1.13 \mathrm{~b}$ \\
\hline
\end{tabular}

${ }^{2}$ Subjective ratings from 1 to $5 ; 1=$ upright, $5=$ prostrate growth habit.

${ }^{y}$ Values within a column followed by the same letter are not significantly different at $P=0.05$ according to a Student's $t$ test with unequal variances.

${ }^{x}$ Predicted mean $\mathrm{P}\left(\mathrm{M}_{\mathrm{F}_{2}}\right)$ obtained by the formula $\mathrm{P}\left(\mathrm{M}_{\mathrm{F}_{2}}\right)=0.25$ $\left(\mathrm{M}_{\mathrm{p} 1}\right)+0.50\left(\mathrm{M}_{\mathrm{F} 1}\right)+0.25\left(\mathrm{M}_{\mathrm{P}_{2}}\right)$.

"Values within a column followed by the same letter are not significantly different at $P=0.05$ according to the $X^{2}$ value with normal distribution of the error.

Predicted variance $\mathrm{P}\left(\mathrm{V}_{\mathrm{F} 2}\right)$ obtained by the formula $\mathrm{P}\left(\mathrm{V}_{\mathrm{F}_{2}}\right)=$ $0.25\left(\mathrm{M}_{\mathrm{P} 1}{ }^{2}\right)+0.50\left(\mathrm{M}_{\mathrm{F} 1}{ }^{2}\right)+0.25\left(\mathrm{M}_{\mathrm{P} 2}{ }^{2}\right)-\mathrm{P}\left(\mathrm{M}_{\mathrm{F} 2}\right)^{2}$.

The mean and variance data do not support a single-gene model for PGH within the populations observed.

Prostrate growth habit resulted in a more-open plant habit. Based on greenhouse measurements, the lateral branches grew from the main stem of the plant at a greater angle. Data taken from field-grown plants gave the same results. At the node just below the first inflorescence, both apices grew with equal vigor; yet growth of these apices was probably equivalent to that of the laterals. As the plant matured, it became more open, often producing a characteristic split at the node immediately below the first inflorescence, likely due to the weight of the proximal fruit. The first two clusters of fruit were in the center of the plant, clearly visible and easily harvested by hand. Subsequent clusters of fruit were toward the edge of the plant, with more foliage cover.

$L p$, described earlier, is phenotypically distinct from $\mathrm{PGH}$, though it is derived from similar ancestry. PGH does not result in an increase in number of lateral branches or early termination of the main axis, as does $L p$. In addition, a split at the main branch angle and central concentration of fruit, which are characteristics of PGH, are not associated with $L p$ (I.L. Nonnecke, personal communication). Genetically, PGH appears to be quantitative in inheritance, whereas $L p$ is qualitative.

Estimates of genotype $\times$ environment interactions could not be calculated because the experiment was run in only one location for 1 year. Thus, there could be an upward bias in estimates for genotypic and additive variances, as well as heritabilities. Since estimates of nonadditive variance are negative (Table 4), this pattern is likely. Accidental self-pollinations likely were absent since the jointed pedicel character showed the expected segregation ratio (data not shown).

Use of a subjective rating scale appeared to be an effective selection method for PGH. Angle measurement was not precise; it was difficult to obtain an accurate angle measurement within $3^{\circ}$. The measurement of angles required much more time to accomplish, making it less suitable for a breeding program. Furthermore, heritability was estimated to be high using the subjective rating system, so there would be little gained for the added effort of angle measuring. 
Plant vigor proved to be a hindrance in the study. As plants grew larger, it became more difficult to give a definitive rating. One possible way to avoid this problem would be the use of wider rows and greater space between plants within the row. $\mathrm{PGH}$ has now been combined with the brachytic $(b r)$ gene for shorter internodes, resulting in a more-compact plant. This trait should be helpful in reducing the problem of excessive growth masking the effects of PGH.

\section{Literature Cited}

Barton, D.W., L. Butler, J.A. Jenkins, C.M. Rick, and P.A. Young. 1955. Rules for nomenclature in tomato genetics (including a list of known genes). J. Hered. 46:22-26.

Campbell, C.G. and I.L. Nonnecke. 1974. Inheritance of an enhanced branching character in tomato (Lycopersicon esculentum Mill.). J. Amer. Soc. Hort. Sci. 99:358-360.

Clayburg, C.D., L. Butler, E.A. Kerr, C.M. Rick, and R.W. Robinson. 1966. Third list of known genes in tomato (with revised linkage map and additional rules). J. Hered. 57:188-196.

Clayburg, C.D., L. Butler, E.A. Kerr, C.M. Rick, and R.W. Robinson. 1979. Report of gene list committee. Tomato Genet. Coop. 29:2-17.
Fisher, R.A. and F. Yates. 1963. Statistical tables for biological, agricultural and medical research. Hafner, New York.

Gardner, R.G. 1985. 'Piedmont' tomato. HortScience 20:960-961.

Lindsey, M.F., J.H. Lonnquist, and C.O. Gardner. 1962. Estimates of genetic variance in open-pollinated varieties of cornbelt corn. Crop Sci. 2:105-108.

Ozminkowski, R.H., Jr. 1988. The inheritance of prostrate growth habit in tomato. MS Thesis, North Carolina State Univ., Raleigh.

Ozminkowski, R.H., Jr., R.G. Gardner, W.R. Henderson, and R.H. Moll. 1990. Prostrate growth habit enhances fresh market tomato fruit yield and quality. HortScience (In press.)

Steele, R.G.D. and J.H. Torrie. 1980. Principles and procedures of statistics. 2nd ed. McGraw-Hill, New York.

Stubbe, H. 1959. Mutanten de kulturtomate Lycopersicon esculentum Mill. III. Kulturpflanze 7:82-112.

Stubbe, H. 1960. Mutanten der wildtomate Lycopersicon pimpinellifolium (Jusl.). Mill. II. Kulturpflanze 8:110-137.

Warner, J.N. 1952. A method for estimating heritability. Agron. J. 44:427-430.

Wright, S. 1968. Evolution and the genetics of populations. vol. I. Genetic and biometric foundations. Univ. of Chicago Press, Chicago. 